\title{
FEATURE Carbon sequestration in agricultural lands of the United States
}

Jack A. Morgan, Ronald F. Follett, Leon Hartwell Allen, Jr., Stephen Del Grosso, Justin D. Derner, Feike Dijkstra, Alan Franzluebbers, Robert Fry, Keith Paustian, and Michele M. Schoeneberger

$\mathbf{R}$ educing concentrations of carbon dioxide $\left(\mathrm{CO}_{2}\right)$ and other greenhouse gases (GHG) in Earth's atmosphere is identified as one of the most pressing modern-day environmental issues (IPCC 2007). As a signatory country to the United Nations Framework Convention on Climate Change (UNFCCC), the United States is actively engaged in a critical international effort to find solutions to the problems posed by climate change. Agriculture, in addition to being affected by the climate, contributes to climate change through its exchanges of GHG with the atmosphere. Thus, the management of agricultural systems to sequester atmospheric $\mathrm{CO}_{2}$ as soil organic carbon (SOC) and to minimize GHG emissions has been proposed as a partial solution to the climate change problem. In this paper, we discuss the potential role of agriculture in the United States to mitigate climate change through sequestration of carbon (C). We also identify critical knowledge gaps where further research is needed.

Carbon enters terrestrial ecosystems, including agriculture, through photosynthesis by green plants that assimilate $\mathrm{CO}_{2}$

Jack A. Morgan is plant physiologist and Feike Dijkstra is post-doc research ecologist at the Rangeland Resources Research Unit, Ronald F. Follett is research leader and soil scientist and Stephen Del Grosso is a soil scientist and ecologist at the Soil Plant Nutrient Research Unit, USDA Agricultural Research Service Northern Plains Area, Fort Collins, Colorado. Leon Hartwell Allen Jr. is soil scientist at the Chemistry Research Unit, USDA Agricultural Research Service South Atlantic Area, Gainesville, Florida. Justin D. Derner is rangeland scientist at the Rangeland Resources Research Unit, USDA Agricultural Research Service Northern Plains Area, Cheyenne, Wyoming. Alan Franzluebbers is ecologist at the Natural Resource Conservation Center, USDA Agricultural Research Service South Atlantic Area, Watkinsville, Georgia. Robert Fry is state conservation agronomist, USDA Natural Resources Conservation Service, Davis, California. Keith Paustian is professor at the Department of Soil and Crop Sciences, Colorado State University, Fort Collins, Colorado. Michele $\boldsymbol{M}$. Schoeneberger is research leader and soil scientist at the National Agroforestry Center, Lincoln, Nebraska.

\section{Figure 1}

The terrestrial carbon cycle. Inputs of carbon (C) into the soil organic C (SOC) pool originate from the fixation of atmospheric $\mathrm{CO}_{2}-\mathrm{C}$ through photosynthesis by plants into simple sugars, and subsequently into the more complex materials (i.e., cellulose and lignin), eventually deposited in their leaves, stems, and roots. Plant material and its organic $C$ can be consumed by animals or become humified into soil organic matter (SOM), which contains SOC, through the action of microorganisms. Carbon storage as SOC is controlled by the soil environment and the quality of the organic matter in which the carbon resides. Decomposition is the biological conversion of organic matter into more oxidized constituents, including $\mathrm{CO}_{2}$, which is released back to the atmosphere. Decomposition rates are affected by soil structure and by soil temperature and moisture conditions.

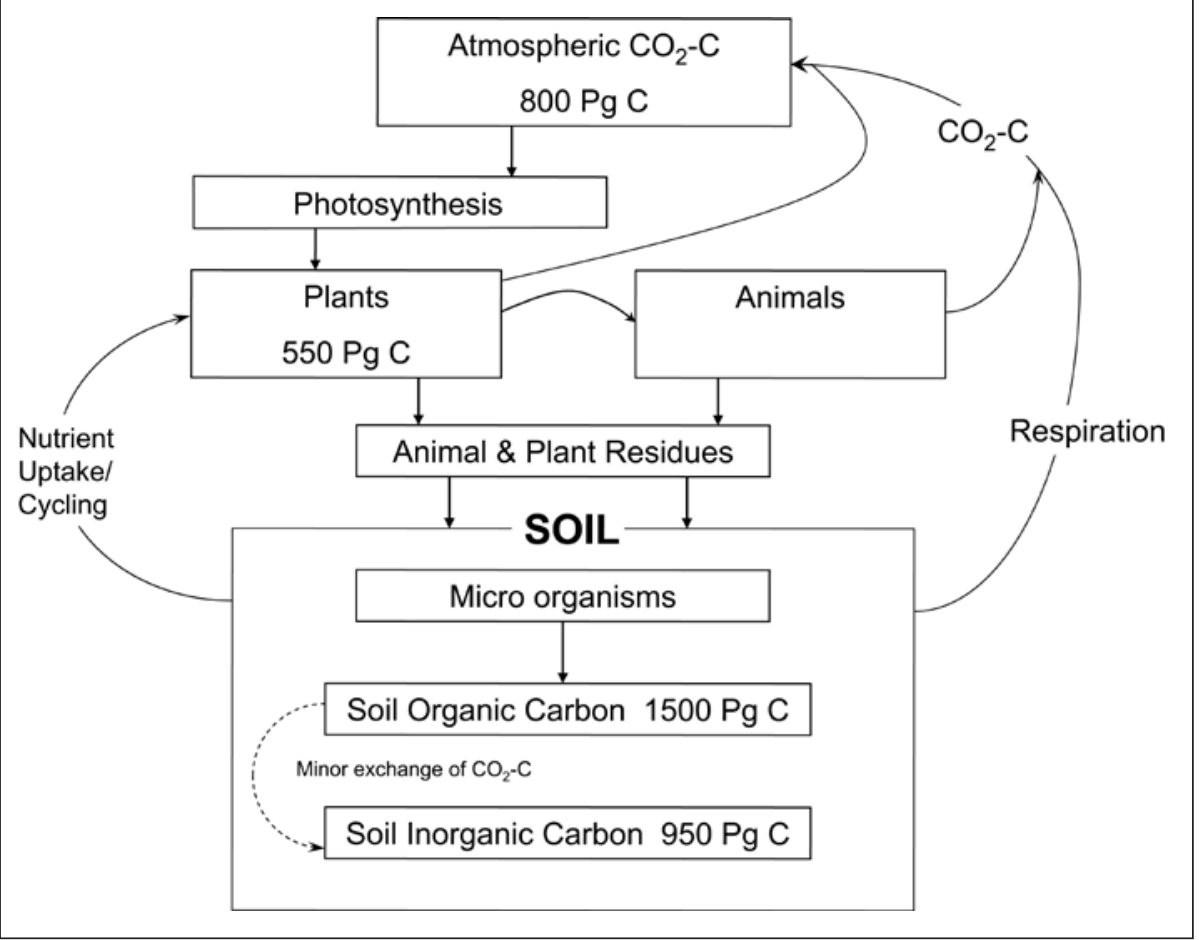

and fix it into organic forms (figure 1). Some C eventually enters the soil, where its subsequent cycling and storage among SOC and soil inorganic carbon (SIC) pools determine its residence time and ultimately its return back to the atmosphere. The rate of photosynthetic $\mathrm{CO}_{2}$ assimilation depends on soil fertility, climate, and management, which, in addition to other soil and plant factors, influence rates of $\mathrm{C}$ return to the atmosphere. Three major thrusts of GHG mitigation research in agriculture are (1) developing management practices to enhance the assimilation of atmospheric $\mathrm{CO}_{2}$ by vegetation, (2) managing the movement of $\mathrm{C}$ from the plants/animals into the soil, and (3) altering the cycling of SOC to increase its residence time. Sequestering $\mathrm{C}$ within the soil organic matter (SOM) is among the best options for $\mathrm{C}$ storage in terrestrial ecosystems. Besides helping offset $\mathrm{CO}_{2}$ emissions into Earth's atmosphere, C sequestration into SOM provides multiple benefits, such as improved soil quality through enhanced fertility, soil structure and aggregate stability, water holding capacity, and the capacity to reduce toxic elements.

Two other gases additional to $\mathrm{CO}_{2}-$ methane $\left(\mathrm{CH}_{4}\right)$ and nitrous oxide $\left(\mathrm{N}_{2} \mathrm{O}\right)$ - are important agricultural GHG and deserve mentioning. Agricultural $\mathrm{CH}_{4}$ emissions occur primarily from livestock through enteric fermentation and from 
wetland systems like rice, with emission rates being sensitive to soil nitrogen $(\mathrm{N})$, water availability, soil $\mathrm{pH}$, and amounts and forms of SOC. Nitrous oxide emissions from agriculture are largely the result of $\mathrm{N}$ fertilizer additions. While our focus will be primarily on soil C, we will mention non- $\mathrm{CO}_{2}$ trace gases (1) to the extent their fluxes are affected by $\mathrm{C}$ sequestration management and (2) in the context of wetland agriculture, where $\mathrm{CH}_{4}$ fluxes are important in the $\mathrm{C}$ balance.

\section{CARBON POOLS AND SEQUESTRATION}

Global C can be partitioned into five large pools: oceanic $38,000 \mathrm{Pg} \mathrm{C}$, where $\mathrm{Pg}=$ petagram $=10^{15} \mathrm{~g}[42,000$ billion tn]); geologic (5,000 Pg [5,500 billion tn]); pedologic, or soils-based (2,460 Pg [2,710 billion $\mathrm{tn}]-1,500 \operatorname{Pg}[1,650$ billion $\mathrm{tn}]$ in SOC and $950 \mathrm{Pg}[1,050$ billion $\mathrm{tn}]$ in SIC); atmospheric (800 Pg [887 billion $\mathrm{tn}]$, increasing at the rate of $\sim 4.1 \mathrm{Pg} \mathrm{C} \mathrm{yr}^{-1}[4.5$ billion tn $\mathrm{yr}^{-1}$ ] [IPCC 2007]); and biotic C (550 Pg [606 billion tn]) (Houghton 2007; Lal 2004, 2006). Approximately 9 Pg $(9.9$ billion $\mathrm{tn}$ ) of $\mathrm{C}$ is presently released to the atmosphere each year from burning fossil fuels and industrial activity, and another $\sim 1.5 \mathrm{Pg}$ (1.7 billion tn) is released from deforestation and land use change (Global Carbon Project 2009). Each year, about $60 \mathrm{Pg}$ (66 billion tn) $\mathrm{C}$ is exchanged in each direction between terrestrial ecosystems and the atmosphere. Although 84\% of US net $\mathrm{C}$ emissions are from fossil fuel consumption and only $7 \%$ from agriculture, the nearly 2,500 Pg (2,800 billion tn) $\mathrm{C}$ stored in terrestrial soils and the $60 \mathrm{Pg}$ (66 billion tn) $\mathrm{C}$ exchange with the atmosphere will be important in the next few decades to buy time while new, C-saving, -capture, and -sequestration technologies are developed. However, even as new strategies and technologies are developed, it will remain important for agriculture to continue developing and implementing successful soil $\mathrm{C}$ sequestration practices which maintain or enhance SOC and SIC pools (figure 2).The following sections will briefly review our present knowledge of recommended management practices for important US agricultural sectors. At the end of each section, critical research gaps and/or development needs for enhancing

\section{Figure 2}

Strategies for carbon sequestration. Strategies for enhancing carbon (C) sequestration may be achieved either through increasing soil organic C (SOC) or soil inorganic $\mathrm{C}$ (SIC) pools. For SOC, this encompasses practices which increase the sequestration efficiency of $C$ inputs, improve soil structure, or decrease SOC losses. Increases in the SIC pool result from such management practices as biosolids application, liming, and conservation of water within the root zone.

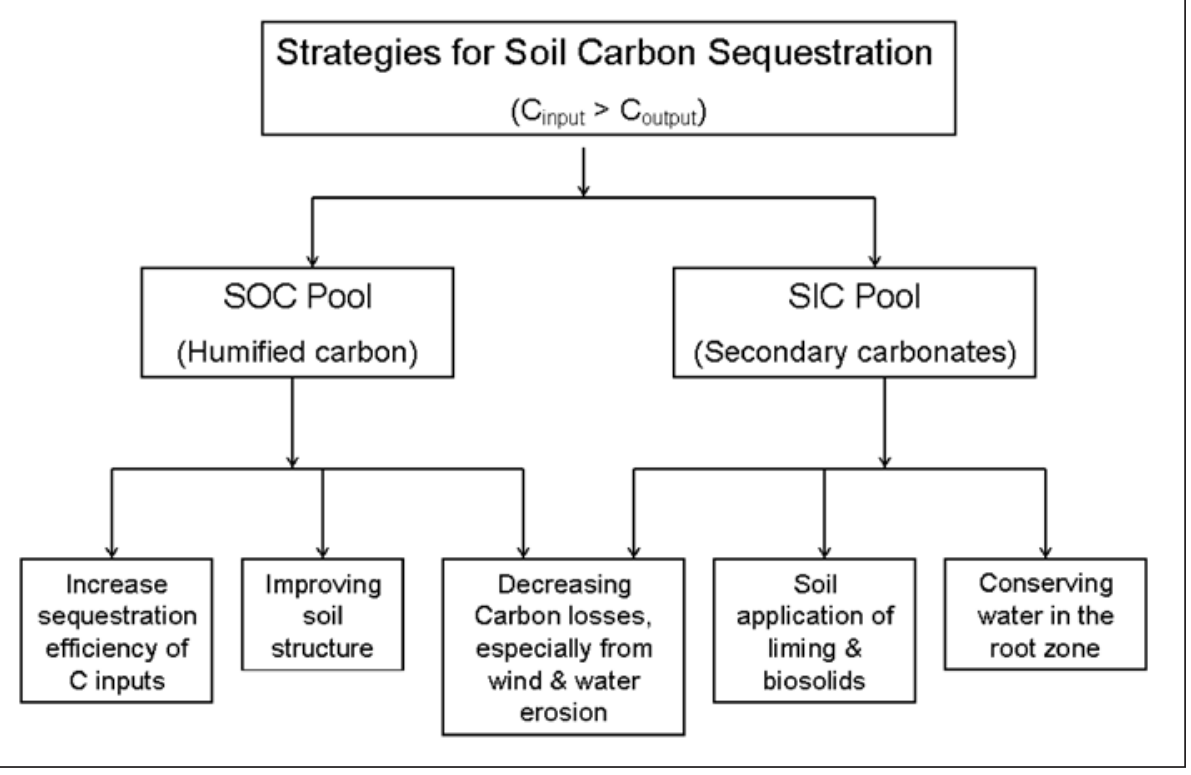

US agriculture's $C$ sequestration capabilities are identified, which are listed together in abbreviated form in table 1.

\section{AGRICULTURAL SECTORS}

Cropping Systems. In 2002, harvested croplands in the United States covered about 179 Mha (442 million ac), including 138 Mha (340 million ac) used for crops, 16 Mha (40 million ac) as idle cropland, and 25 Mha (62 million ac) as pasture (USDA NASS 2008a; USDA NRCS 2003). Recommended management practices to increase SOC in croplands include increasing cropping frequency and growing high-residue crops. Alternatively, soil C losses can be minimized by reducing soil tillage (effectiveness is soil type and crop dependent), maximizing plant water use efficiency (more efficient rotations and improved irrigation management), and application of surface mulches that shade the soil (Follett 2001). Incorporation of perennial grasses and grass/legume mixtures can be especially effective to allocate a higher percentage of plant biomass $\mathrm{C}$ to belowground soil $\mathrm{C}$ sequestration, extend the growing season, better utilize soil water, and reduce tillage disturbance com- pared to annual crops. Improved practices on croplands can increase SOC sequestration rates to 0.1 to $1 \mathrm{Mg}(\mathrm{Mg}=$ megagram $\left.=10^{6} \mathrm{~g}\right) \mathrm{C} \mathrm{ha}^{-1} \mathrm{yr}^{-1}$ (89 to $890 \mathrm{lb} \mathrm{C} \mathrm{ac}^{-1}$ $\mathrm{yr}^{-1}$ ), with accumulation rates diminishing as soils approach new equilibria (CAST 2004). Higher rates are expected in the conversion of annual croplands to perennial grasses/legumes as conservation set-asides or pastures (Conant et al. 2001; Follett 2001).

Critical research needs for further enhancing C sequestration of cropped systems include (1) clarifying the interactions among tillage, climate, and soil type on $\mathrm{C}$ sequestration, (2) quantifying aboveand below-ground plant contributions to SOC, and (3) evaluating $\mathrm{C}$ sequestration practices for total GHG emissions, since recommended practices like incorporation of legumes or fertilizer additions, which enhance soil $\mathrm{C}$, may enhance the soil release of $\mathrm{N}_{2} \mathrm{O}$ (table 1).

Grazinglands. About $37 \%$ of the total land area in the US (236 Mha [580 million ac]) was occupied by grazinglands in 2002 (USDA ERS 2007), thereby contributing about $15 \%$ to US soil C sequestration potential (Lal et al. 2003). Grazingland 


\section{Table 1}

Critical research needs for developing and implementing US agricultural carbon sequestration and non- $\mathrm{CO}_{2}$ greenhouse gases mitigation practices.

\begin{tabular}{|c|c|}
\hline Topics & Critical needs \\
\hline \multicolumn{2}{|l|}{ Agricultural sectors } \\
\hline Cropping systems & $\begin{array}{l}\text { - Clarify tillage and environnent interactions on soil C } \\
\text { - Quantify above- and belowground C contributions } \\
\text { - Evaluate C practices for total GHG emissions }\end{array}$ \\
\hline Grazinglands & $\begin{array}{l}\text { - Quantify C sequestration in arid shrublands } \\
\text { - Evaluate species mixtures for soil C sequestration and } \\
\text { minimizing total GHG emissions } \\
\text { - Evaluate management and environment interactions } \\
\text { on C sequestration }\end{array}$ \\
\hline Agroforestry & $\begin{array}{l}\text { - Quantify C dynamics in agroforesty systems } \\
\text { - Find effective strategies for measuring/monitoring C } \\
\text { sequestration in soil and woody components } \\
\text { - Develop and implement national inventory }\end{array}$ \\
\hline Horticulture & $\begin{array}{l}\text { - Evaluate feasible practices for storing soil C } \\
\text { - Quantify C sequestration in promising systems } \\
\text { - Evaluate benefits beyond C sequestration }\end{array}$ \\
\hline Turfgrass & $\begin{array}{l}\text { - Incorporate effects of urbanization in national C estimates } \\
\text { - Quantify } \mathrm{C} \text { sequestration for various urban uses } \\
\text { - Evaluate the role of turfgrass systems on the emission } \\
\text { of non- } \mathrm{CO}_{2} \text { trace gases }\end{array}$ \\
\hline Potential high flux areas & $\begin{array}{l}\text { - Perform research and management for minimizing } \mathrm{CH}_{4} \text { and } \\
\mathrm{N}_{2} \mathrm{O} \text { fluxes in rice and other crops grown on organic soils }\end{array}$ \\
\hline \multicolumn{2}{|c|}{ Regional and national scale analyses } \\
\hline Measurements/monitoring & $\begin{array}{l}\text { - Develop low-cost C/GHG monitoring systems and integrate } \\
\text { with soil sampling network, modeling, and remote sensing } \\
\text { - Improve and develop models of C/GHG fluxes from different } \\
\text { agricultural sectors for scaling to regional and national } \\
\text { - Enhance remote sensing tools for quantifying C/GHG fluxes }\end{array}$ \\
\hline Databases & $\begin{array}{l}\text { - Expand soil C/GHG monitoring networks } \\
\text { - Develop national agricultural C/GHG database }\end{array}$ \\
\hline \multicolumn{2}{|l|}{ Emerging issues } \\
\hline Biofuels & $\begin{array}{l}\text { - Evaluate } \mathrm{SOC} \text { responses to biofuel operations, including } \\
\text { marginal lands } \\
\text { - Clarify relationships between } \mathrm{C} \text { storage and non- } \mathrm{CO}_{2} \mathrm{GHG} \text { fluxes } \\
\text { - Evaluate implications of biofuel on } \mathrm{C} \text { stores of } \mathrm{CRP} \text {, } \\
\text { grasslands, and forests }\end{array}$ \\
\hline Climate change & $\begin{array}{l}\text { - Perform process-level research on multiple climate } \\
\text { change factors } \\
\text { - Develop models to predict future impacts of climate } \\
\text { change on C and GHG fluxes } \\
\text { - Develop observational and monitoring systems for tracking } \\
\text { climate change impacts on agroecosystem C stores }\end{array}$ \\
\hline
\end{tabular}

soil $\mathrm{C}$ sequestration is affected by climate (Derner et al. 2006; Jones and Donnelly 2004; Ingram et al. 2008; Svejcar et al. 2008), biome (Conant et al. 2001), and management (grazing, $\mathrm{N}$ inputs, restoration) (Derner and Schuman 2007). Rangeland management with proper stocking rates, adaptive management, and destocking during drought can result in sequestration of $11 \mathrm{Tg} \mathrm{C} \mathrm{yr}^{-1}(1 \mathrm{Tg}=$ $\left.10^{12} \mathrm{~g}\right)\left(12\right.$ million tn ${\mathrm{C} \mathrm{yr}^{-1}}^{-1}$ nationwide. Sequestration rates decline in rangelands over time without added inputs, and the greatest potential gains are on marginal or poorly-managed lands (Conant et al. 2001; Conant and Paustian 2002; Derner and Schuman 2007; Swift 2001). The amount of $\mathrm{C}$ stored in improved pasturelands (mostly mesic systems characteristic of the eastern United States) can be double that of cropland and can be enhanced by adjusting stocking rate, plant species, and fertilizer additions; although, the later can reduce the $\mathrm{C}$ advantage through increased emissions of $\mathrm{N}_{2} \mathrm{O}$ (Franzluebbers 2005). Rates of SOC sequestration under best management practices range from 0.070 to $0.30 \mathrm{Mg} \mathrm{C} \mathrm{ha}^{-1} \mathrm{yr}^{-1}$ (62 to $270 \mathrm{lb} \mathrm{C} \mathrm{ac}^{-1}$ $\mathrm{yr}^{-1}$ ) for rangelands (Schuman et al. 1999, Derner and Schuman 2007) and from 0.30 to $1.4 \mathrm{Mg} \mathrm{C} \mathrm{ha}^{-1} \mathrm{yr}^{-1}$ (270 to $1200 \mathrm{lb}$ $\mathrm{ac}^{-1} \mathrm{yr}^{-1}$ ) for pastures (Schnabel et al. 2001; Franzluebbers 2005).

Critical research needs in grazingland soil C sequestration include (1) quantifying $\mathrm{C}$ sequestration in arid shrublands (almost no data presently), (2) evaluating forage species mixtures for optimizing $\mathrm{C}$ sequestration and minimizing non- $\mathrm{CO}_{2}$ trace gas emissions, and (3) quantifying interactions of management with climate on $\mathrm{C}$ sequestration (table 1 ).

Agroforestry. Agroforestry is the intentional integration of woody plants into crop and livestock systems to improve soil, water and air quality, and wildlife habitat while supporting sustainable production of food, feed, fiber, and energy (Ruark et al. 2003; Garrett 2009). It represents a significant opportunity for sequestering $\mathrm{C}$ on agricultural lands in that a substantial proportion of the $\mathrm{C}$ is sequestered in woody biomass, thus creating a system that sequesters a large amount of $\mathrm{C}$ per unit area and for a longer duration than many other practices (Montagnini and Nair 2004; Schoeneberger 2009). Since agroforestry is not explicitly inventoried within the two major natural resource inventories in the United States - the USDA Forest Service Forest Inventory Analysis and the USDA Natural Resources Conservation Service (NRCS) Natural Resources Inventory 
(Perry et al. 2009)-its potential contributions to $\mathrm{C}$ sequestration have been estimated based on assumptions of where these plantings would suitably occur for services other than $\mathrm{C}$ sequestration. Using this approach, Nair and Nair (2003) estimated areas either currently under, or which could potentially be brought under, agroforestry practices to encompass 80,70 , and 85 Mha $(200,170$, and 210 million ac) for alley cropping, silvopasture, and windbreaks, respectively, with an additional 0.8 and 2.4 million $\mathrm{km}$ (0.5 and 1.5 million mi) of forested riparian and conservation buffers, respectively. Potential C storage for temperate agroforestry ranges from 15 to $198 \mathrm{Mg} \mathrm{C} \mathrm{ha}^{-1}$ (6.7 to 88 tn $\mathrm{C} \mathrm{ac}^{-1}$ ) (Dixon et al.1994), or approximately $90 \mathrm{Tg}$ $\mathrm{C} \mathrm{yr}^{-1}$ (99 million tn $\mathrm{C} \mathrm{yr}^{-1}$ ) by 2025 for the United States (Nair and Nair 2003).

Critical research needs in agroforestry include (1) quantifying $\mathrm{C}$ dynamics in agroforestry systems, (2) developing effective strategies for measuring and monitoring $\mathrm{C}$ sequestration in soil and woody components, and (3) developing/implementing a national inventory of agroforestry (table 1).

Horticulture. Little attention has been paid to $\mathrm{C}$ sequestration in vegetable, orchard, and vineyard crops. US land area of vegetable crops is nearly 0.80 Mha $(2.0$ million ac), plus 0.50 Mha (1.2 million ac) in potatoes and 1.6 Mha (3.9 million ac) in tree (fruit and nut) crops (USDA NASS 2008a). Land area in vineyards is uncertain, although about $87 \%$ of all types are grown in California, and the total US production of grapes in 2007 was $6.1 \mathrm{Tg}$ (6.7 million tn) on a fresh basis (USDA NASS 2008a). Specialized field management practices and diverse rotations have discouraged the use of conservation tillage in most vegetable operations, including those under arid, irrigated conditions in California. The timing of critical management practices to achieve optimum market timing can impact these highvalue cash crops and dampen efforts to sequester soil C. However, limited research suggests promising uses of cover crops for promoting increased soil C storage in vegetable (Al-Sheikh et al.2005) and vineyard (Steenwerth and Belina 2008) systems. Further, cover crops offer many benefits beyond $\mathrm{C}$ sequestration, such as increasing soil fertility and enhancing disease control (Delgado et al. 2007).

More research is needed in horticultural systems to (1) evaluate potentially feasible horticultural management practices for storing soil $\mathrm{C}$, (2) quantify $\mathrm{C}$ sequestration in promising horticultural systems, and (3) further evaluate benefits of conservation practices beyond $\mathrm{C}$ sequestration (table 1 ).

Turfgrass. Although not an agricultural enterprise in the usual sense, turfgrass represents an important feature on the US landscape in regard to C (Jenkins 1994). Many land areas previously used for agriculture have now become part of the urban landscape, including lands that have been converted to C-sequestering turfgrasses. Rates of SOC sequestration under turf have a fairly broad range, from 0.32 to $\sim 1 \mathrm{Mg} \mathrm{C} \mathrm{ha}^{-1} \mathrm{yr}^{-1}$ (290 to $890 \mathrm{lb} \mathrm{ac}^{-1} \mathrm{yr}^{-1}$ ) (Banaranayake et al. 2003; Huh et al. 2008; Qian et al. 2010; Qian and Follett 2002). Using the lowest rate of sequestration of about $0.32 \mathrm{Mg} \mathrm{C} \mathrm{ha}^{-1} \mathrm{yr}^{-1}\left(290 \mathrm{lb} \mathrm{C} \mathrm{ac}^{-1}\right.$ $\mathrm{yr}^{-1}$ ) applied to the $16 \mathrm{Mha}$ (40 million ac) of turfgrass reported by Milesi et al. (2005), we estimate that about $5 \mathrm{Tg}$ (5.5 million tn) $\mathrm{C}$ are sequestered by turfgrass systems across the continental United States each year. Critical needs in turfgrass include (1) knowledge to incorporate the combined effects of urbanized land area expansion with agricultural land area losses into national estimates of soil $\mathrm{C}$ sequestration, (2) improved quantification of rates and areas for $\mathrm{C}$ sequestration under various urban land uses, and (3) obtaining a better understanding of the role that growing turfgrass may have on emissions of other GHGs such as $\mathrm{N}_{2} \mathrm{O}$ and $\mathrm{CH}_{4}$ (table 1).

Wetlands and Organic Soils. Although organic soils and wetland agriculture each constitute $\sim 1 \%$ or less of cropped areas in the United States, their high rates of GHG emissions deserve special attention. Organic soils develop under waterlogged conditions, where lack of oxygen inhibits organic matter decomposition. However, with drainage, microbial oxidation of the organic matter causes them to subside and release $\mathrm{CO}_{2}$ at high rates. Approximately $7.5 \%$ of the 10 Mha (25 million ac) of organic soils in the United States have been drained for agriculture, with about half in Florida and California and the remainder mostly in Minnesota, Michigan, Wisconsin, Indiana, Iowa, Illinois, New York, North Carolina, and South Carolina. Annual $\mathrm{CO}_{2}$ emissions from soils in the Everglades Agricultural Area (EAA) in Florida were estimated to release about $25.4 \mathrm{Mg} \mathrm{CO}_{2}-\mathrm{C} \mathrm{ha}{ }^{-1}$ (11.3 tn $\mathrm{CO}_{2}-\mathrm{C}$ $\left.\mathrm{ac}^{-1}\right)$, which is equivalent to $6.93 \mathrm{Mg} \mathrm{C}$ $\mathrm{ha}^{-1}$ (3.08 tn $\mathrm{C} \quad \mathrm{ac}^{-1}$ ) (Allen 2007). However, estimated emissions rates have dropped about 43\% (3.95 Mg C ha ${ }^{-1}$ [1.76 tn $\left.\mathrm{C} \mathrm{ac}^{-1}\right]$ ) following declining rates of soil subsidence (Snyder 2005) in more recent years. Recent emissions estimates for 240,000 ha $(590,000 \mathrm{ac})$ of the EAA constitute a loss of $3.46 \mathrm{Tg} \mathrm{C} \mathrm{yr}^{-1}$ (3.81

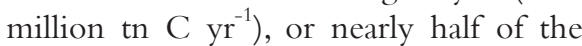
total $7.55 \mathrm{Tg} \mathrm{C} \mathrm{yr}^{-1}$ (8.31 million tn $\mathrm{C}$ $\left.\mathrm{yr}^{-1}\right)$ of estimated emissions from US organic soils (EPA 2008). An estimate of C annual emissions from about 100,000 ha $(247,000 \mathrm{ac})$ of the Sacramento-San Joaquin Delta is $2.0 \mathrm{Tg} \mathrm{C} \mathrm{yr}^{-1}$ (2.2 million tn $\mathrm{C} \mathrm{yr}^{-1}$ ) (Rojstaczer and Deverel 1993). Although it is not feasible to consider C sequestration in such soils, reducing the emissions of $\mathrm{GHG}$ is an important goal. Management to combat GHG emissions includes maintaining high water tables and selection of crops that can tolerate periodic flooding. Unfortunately, high water-table strategies, while reducing organic matter decomposition and reducing $\mathrm{CO}_{2}$ emissions, may enhance emissions of both $\mathrm{CH}_{4}$ and $\mathrm{N}_{2} \mathrm{O}$.

In the United States, wetland agriculture is essentially rice. The $1.4 \mathrm{Mha}$ (3.5 million ac) of rice lands in the United States occur in Arkansas, Louisiana, California, Texas, Mississippi, Missouri, and a minor area in Florida (USDA 2008). The anaerobic conditions of flooded rice fields result in methanogenic bacteria generating $\mathrm{CH}_{4}$ as well as $\mathrm{CO}_{2}$, formed by oxidation of $\mathrm{CH}_{4}$ near plant roots. Water table level, temperature, fertilization, irrigation, organic matter (plant residues), and season can all affect emission rates. Conditions in rice fields that diminish $\mathrm{CH}_{4}$ synthesis and release may promote emission of $\mathrm{N}_{2} \mathrm{O}$, thus complicating the development of best management practices that can consider both gases. Strategies to reduce $\mathrm{CH}_{4}$ (and $\mathrm{N}_{2} \mathrm{O}$ ) emissions from rice fields include 
timing of midseason drainage, split fertilizer applications, nitrification inhibitors, avoiding incorporation of fresh organic matter and plant residues, and selection of rice cultivars with low gas transport and low rates of root exudation. Research is needed to develop strategies that minimize emissions of both $\mathrm{CH}_{4}$ and $\mathrm{N}_{2} \mathrm{O}$ for (1) rice cultivation and (2) other major crops grown on organic soils (table 1 ).

\section{REGIONAL AND NATIONAL SCALE ANALYSES}

In addition to the needs articulated previously regarding the science and management for enhancing soil C sequestration, regional/national scale analyses of soil C and GHG emissions/removals are needed to construct national inventories (Lokupitiya and Paustian 2006). We discuss two important components of these analyses: (1) measuring and monitoring, and (2) databases.

Measuring and Monitoring. Low-cost C and non- $\mathrm{CO}_{2}$ GHG information is needed at multiple levels, from single operators up to regional and national levels (Lokupitiya and Paustian 2006). Measuring networks, such as GRACEnet (Greenhouse gas Reduction through Agricultural Carbon Enhancement network) (GRACEnet 2009; Jawson et al. 2005) and the National Resources Inventory (NRI), can provide opportunities to continuously monitor sites over appropriate time scales. A major challenge in quantifying SOC stocks is in designing an efficient sampling scheme. The spatial variability of SOC across most agricultural fields is typically high (Follett et al. 2009), and the amount of C relative to rate of change can also be high, both of which lead to a low signal-to-noise ratio. Thus, a five- to ten-year period of time between sampling may be required to detect changes (Conant and Paustian 2002; Smith 2004), and evaluating significant changes in soil $\mathrm{C}$ across a landscape can require a large number of samples (Garten and Wullschleger 1999). Direct measurements of GHG fluxes can assess the effects of management or climate on $\mathrm{C}$ balance (Baldocchi et al. 2001; Svejcar et al. 2008) and can be used in modeling exercises to estimate large-scale (regional or national) C budgets. However, GHG measure- ment technology is expensive, highly technical, and not usually economically suitable for routine monitoring of longterm management impacts at a particular site. Direct sampling of soil C is a more feasible technique for such quantification. Flexible and cost-effective means for quantifying soil $\mathrm{C}$ changes can be developed by combining standard soil-sampling methodology with process-based modeling, taking into account landscape features and using stratified sampling methods (Mooney et al. 2004; Paustian et al. 2009). Remote sensing offers an additional tool that would be especially useful for quantifying the spatial extent of easily identified mitigation practices like windbreaks and buffer plantings, tillage and residue management, and cover crops. More research is needed (1) to develop low-cost C and GHG monitoring systems that integrate soil sampling networks with process-based modeling and remote sensing tools, (2) to improve/develop models of C sequestration and GHG fluxes to scale up the various agricultural sectors to regional and national levels, and (3) to enhance remote sensing tools for quantifying important indicators of soil C and GHG flux potential (table 1).

Databases. Two main types of data sources are needed for quantifying $\mathrm{C}$ and GHG emissions: (1) measurements of GHG emissions and soil C change (emissions data) for different land use and management systems, climate, and soil types across the United States and (2) information about the management activities (activity data) that influence emissions and how they vary geographically and over time. To fully exploit these types of databases, resources are required to populate, organize, and maintain data in an easily accessible format. Software is required to extract and format driver data for different models and to format model results to facilitate comparisons of outputs with measurements. It is crucial to compare outputs from different models with actual soil C and GHG measurements obtained with different methods to increase confidence in emissions estimates. The data collected include those from direct measurements of soil C (Conant and Paustian 2002); land-atmosphere (Baldocchi et al.
2001; Svejcar et al. 2008) or soil-based exchanges (Franzluebbers and Follett 2005) of various GHG; or estimates, based on various USDA and other government agency databases (USDA 2008), or modeling, using process-based (Del Grosso et al. 2000; Parton et al. 2001) and/or simpler models (Intergovernmental Panel on Climate Change tier 1 and 2 protocols).

Critical needs for the development of a national database include (1) expanding existing soil C and GHG monitoring networks in agricultural sectors to encompass representative agroecosystems and (2) integrating the diverse emissions and activity databases into a unified national database focused on an agricultural C and GHG strategy (table 1).

\section{EMERGING ISSUES}

Implementation of agricultural C sequestration and non- $\mathrm{CO}_{2}$ GHG mitigation practices must take into account two important emerging issues that US agriculture is only beginning to recognize: (1) biofuels and (2) the potential impact of climate change and rising $\mathrm{CO}_{2}$ on $\mathrm{GHG}$ mitigation strategies.

Biofuels. About 140 Mha (350 million ac) of agricultural lands in the United States are active croplands, with corn, soybeans, and wheat representing about two-thirds of this area. About $18 \%$ of the grain harvested from 35 Mha $(86$ million ac) of corn in the United States was used for ethanol production in 2007; more than half of harvested corn grain was for animal feed (USDA NASS 2008b; USDA ERS 2008). A keen interest exists to develop sustainable energy technologies from cellulosic biofuels (Robertson et al. 2008). However, a number of concerns have been raised about possible environmental problems arising from intensification of agriculture (e.g., soil erosion, decrease in soil quality and productivity, loss of nitrate and phosphorous, decline in air quality, decline in biodiversity, increased loss of forests to compensate for cropland lost to biofuel production), some of which may compromise the overall goal of enhancing agroecosystem C. There are many gaps in our knowledge about the potential impact of biofuel energy crops on SOC. Top research priorities include (1) 
evaluating how SOC responds to annual and perennial biofuel cropping systems, including operations on marginal lands; (2) clarifying relationships among soil C storage and fluxes of non- $\mathrm{CO}_{2}$ GHGs for biofuel operations; and (3) examining the implications of biofuel production on $\mathrm{C}$ storage in Conservation Reserve Program (CRP) lands, grass lands, and forested lands (table 1).

Climate Change Feedbacks and $C$ Sequestration. As we become more confident about its trajectory, we are learning that climate change itself may constrain the very practices designed to curb GHG emissions and enhance $\mathrm{C}$ sequestration. Rising atmospheric $\mathrm{CO}_{2}$ generally increases plant production (Brouder and Volenec 2008; Hatfield et al. 2008; Morgan et al. 2004; Runion et al. 2009), which in turn could enhance SOC stocks through greater transfer of plant $\mathrm{C}$ into the soil (Allen et al. 2006). However, rising $\mathrm{CO}_{2}$ often results in higher soil respiration losses (Pendall et al. 2005), which would diminish the benefit of increased plant production on total system C. Rising temperatures in cooler regions may also increase growing-season length, prolong and enhance biological activity, and enhance net $\mathrm{C}$ uptake (Luo et al. 2007). However, extension of the growing season at a time of year when daily light fluxes are already low will have limited benefits for C uptake, especially at northerly latitudes, since photosynthesis will become increasingly light limited (Skinner 2007). Furthermore, the fertilization effect of $\mathrm{CO}_{2}$ on plant productivity observed in short-term experiments may not be sustained because soil nutrients eventually limit plant responses to $\mathrm{CO}_{2}$ (Luo et al. 2004), especially in native systems without fertilizer additions. Climate change may further constrain, eliminate, and even reverse positive production benefits of higher $\mathrm{CO}_{2}$ since higher temperatures enhance evaporative demand and lead to desiccation. By itself, warming also leads to higher SOM decomposition rates, which may further increase $\mathrm{CO}_{2}$ emissions. Thus, while climate change has likely stimulated $\mathrm{C}$ sequestration in the recent past, continued warming may reduce terrestrial $\mathrm{C}$ sequestration later in this century (Heimann and Reichstein 2008;
Pepper et al. 2005). Critical research needs include (1) more process-level research to evaluate how multiple climate change factors affect the functioning of important agroecosystems, (2) modeling exercises that incorporate the latest findings from climate change experiments and project long-term impacts on C sequestration, and (3) observational/monitoring systems for tracking climate change impacts on US agroecosystem attributes (e.g., plant cover, vegetation type) that are likely to be good indicators of C storage potential (table 1).

\section{CONCLUSIONS}

In agriculture, $\mathrm{C}$ sequestration research has tended to focus primarily on productive cropping systems. Too few experiments have specifically addressed best management practices for improving soil C storage, and fewer yet evaluate practices to reduce emissions of non- $\mathrm{CO}_{2}$ trace gases. Research needs to be expanded to less well-defined components of US agriculture. Despite occupying 37\% of total US land area, relatively little research has evaluated how different management practices may affect $C$ sequestration in US rangelands and pasture lands. Even less is known about the management potential for mitigating GHG emissions in the US horticulture industry and for turfgrass. Organic soils and wetlands present especially complex management challenges since they involve significant emissions of more than one GHG, and practices that reduce emissions of one GHG may stimulate another. Agroforestry contributions to GHG mitigation have not been considered in national inventories. Addressing these research needs, including the challenges presented by biofuels development and climate change feedbacks on agricultural GHG emissions, will be critical for giving US agriculture the necessary tools to mitigate climate change. Continued progress on scaling and monitoring methodologies will be essential to implement regional/national analyses and assessments that climate change policies and protocols will demand.

\section{ACKNOWLEDGEMENTS}

We would like to thank R. Howard Skinner and Greg McMaster for reviews of this manuscript and also Ann Heckart for assistance in document preparation. This publication is based upon work supported by the Agricultural Research Service under the ARS GRACEnet Project.

\section{REFERENCES}

Allen, L.H., Jr. 2007. Carbon balance of sugarcane agriculture on Histosols of the Everglades Agricultural Area: Review, analysis, and global energy perspectives. Soil and Crop Science Society of Florida-Proceedings 66:7-14.

Allen, L.H., Jr., S.L. Albrecht, K.J. Boote, J.M.G. Thomas, Y.C. Newman, and K.W. Skirvin. 2006. Soil organic carbon and nitrogen accumulation in plots of rhizoma perennial peanut and bahiagrass grown in elevated carbon dioxide and temperature. Journal of Environmental Quality 35:1405-1412.

Al-Sheikh, A., J.A. Delgado, K. Barbarick, R. Sparks, M. Dillon, Y. Qian, and G. Cardon. 2005. Effects of potato-grain rotations on soil erosion, carbon dynamics and properties of rangeland sandy soils. Soil and Tillage Research 81:227-238.

Baldocchi, D., E. Falge, L. Gu, R. Olson, D. Hollinger, S. Running, P. Anthoni, Ch. Bernhofer, K. Davis, R. Evans, J. Fuentes, A. Goldstein, G. Katul, B. Law, X. Lee, Y. Malhi, T. Meyers, W. Munger, W. Oechel, K. T. Paw U, K. Pilegaard, H. P. Schmid, R. Valentini, S. Verma, T. Vesala, K. Wilson, and S. Wofsy. 2001. FLUXNET:A new tool to study the temporal and spatial variability of ecosystem-scale carbon dioxide, water vapor, and energy flux densities. Bulletin of the American Meteorological Society 82:2415-2434.

Bandaranayake, W., Y. Qian, W.J. Parton, D.S. Ojima, and R.F. Follett. 2003. Estimation of soil organic carbon changes in turfgrass systems using the CENTURY model. Agronomy Journal 95:558-563

Brouder, S.M. and J.J. Volenec. 2008. Impact of climate change on crop nutrient and water use efficiencies. Physiologia Plantarum 133:705-724.

CAST (Council for Agricultural Science and Technology). 2004. Climate Change and Greenhouse Gas Mitigation: Challenges and Opportunities for Agriculture. Ames, IA: CAST.

Conant, R.T. and K. Paustian. 2002. Spatial variability of soil organic carbon in grasslands: implications for detecting change at different scales. Environmental Pollution 116:127-135.

Conant, R.T., K. Paustian, and E.T. Elliott. 2001. Grassland management and conversion into grassland: Effects on soil carbon. Ecological Applications 11:343-355. 
Delgado, J.A., M.A. Dillon, R.T. Sparks, and S.Y.C. Essah. 2007. A decade of advances in cover crops: Cover crops with limited irrigation can increase yields, crop quality, and nutrient and water use efficiencies while protecting the environment. Journal of Soil and Water Conservation 62:110A-117A.

Del Grosso, S.J. W.J. Parton, A.R. Mosier, D.S. Ojima, C.S. Potter, W. Borken, R. Brumme, K. Butterbach-Bahl, P.M. Crill, and K. Dobbie. 2000. $\mathrm{CH} 4$ oxidation model and comparisons of $\mathrm{CH}_{4}$ oxidation in natural and managed systems. Global Biogeochemical Cycles 14(4):999-1020.

Derner, J.D., T.W. Boutton, and D.D. Briske. 2006. Grazing and ecosystem carbon storage in the Northern US Great Plains. Plant and Soil 280-77-90.

Derner, J.D., and G.E. Schuman. 2007. Carbon sequestration and rangelands: A synthesis of land management and precipitation effects. Journal of Soil and Water Conservation 62:77-85.

Dixon, R.K., J.K. Winjum, K.J. Andrasko, J.J. Lee, and P.E. Schroeder. 1994. Integrated systems: assessment of promising agroforestry and alternative land use practices to enhance carbon conservation and sequestration. Climatic Change 27:71-92.

Follett, R.F. 2001. Soil management concepts and carbon sequestration in cropland soils. Soil and Tillage Research 61:77-92.

Follett, R.F., J.M. Kimble, E.G. Pruessner, S. SamsonLiebig, and S. Waltman. 2009. Soil organic C stocks with depth and land use at various US sites. In Soil Carbon Sequestration and the Greenhouse Effect, 2nd ed., SSSA Special Publication 57, ed. R. Lal, and R.F. Follett, 29-46. Madison, WI: ASA-CSSA-SSSA.

Franzluebbers, A.J. 2005. Soil organic carbon sequestration and agricultural greenhouse gas emissions in the southeastern US. Soil and Tillage Research 83:120-147.

Franzluebbers,A.J., and R.F. Follett. 2005. Greenhouse gas contributions and mitigation potential in agricultural regions of North America. Soil and Tillage Research 83:1-8.

Garrett,H.E., ed. 2009. North American Agroforestry: An integrated Science and Practice. 2nd ed. Madison, WI: American Society of Agronomy.

Garten, C.T., and S.D. Wullschleger. 1999. Soil carbon inventories under a bioenergy crop (Switchgrass): Measurement limitations. Journal of Environmental Quality 28:1359-1365.

Global Carbon Project. 2009. Carbon budget 2008: An annual update of the global carbon budget and trends. http://www.globalcarbonproject. org/carbonbudget/index.htm

GRACEnet. 2009. Greenhouse gas Reduction through Agricultural Carbon Enhancement network. Washington, DC: USDA Agricultural Research Service. http://www.ars.usda. gov/research/GRACEnet.

Hatfield, J.L., K.J. Boote, B.A. Kimball, D.W. Wolfe, D.R. Ort, C.R. Izaurralde, A.M. Thomson, J.A. Morgan, H.W. Polley, P.A. Fay, T.L. Mader, and G.L. Hahn. 2008. Agriculture. In The Effects of Climate Change on Agriculture, Land Resources, Water Resources, and Biodiversity. Washington, DC: US Climate Change Science Program and the Subcommittee on Global Change Research.

Heimann, M., and M. Reichstein. 2008. Terrestrial ecosystem carbon dynamics and climate feedbacks. Nature 451:289-292.

Houghton, R.A. 2007. Balancing the global carbon budget. Annual Review Of Earth and Planetary Science 35:313-347.

Huh, K.Y., M. Deurer, S. Sivakumaran, K. McAuliffe, and N.S. Bolan. 2008. Carbon sequestration in urban landscapes: the example of a turfgrass system in New Zealand. Australian Journal of Soil Research 46:610-616.

Ingram, L.J., P.D. Stahl, G.E. Schuman, J.S. Buyer, G.F. Vance, G.K. Ganjegunte, J.M. Welker, and J.D. Derner. 2008. Grazing impacts on soil carbon and microbial communities in a mixed-grass ecosystem. Soil Science Society of America Journal 72:939-948.

IPCC (Intergovernmental Panel on Climate Change). 2007. Climate Change 2007: Mitigation of Climate Change. Working Group III. Cambridge, UK: Cambridge University Press.

Jawson, M.D., S.R. Shafer, A.J. Franzluebbers, T.B. Parkin, and R.F. Follett. 2005. GRACEnet: Greenhouse gas reduction through agricultural carbon enhancement network. Soil and Tillage Research 83:167-172.

Jenkins,V.S. 1994.The lawn:A history of an US obsession. Washington, DC: Smithsonian Institution Press.

Jones, M.B., and A. Donnelly. 2004. Carbon sequestration in temperate grassland ecosystems and the influence of management, climate and elevated $\mathrm{CO}_{2}$. New Phytologist 164:423-439.

Lal, R. 2004. Soil carbon sequestration impacts on global climate change and food security. Science 304:1623-1627.

Lal, R. 2006. Soil carbon sequestration in Latin America. In: Carbon Sequestration in Soils of Latin America, ed. R. Lal, C. Cerri, M. Bernoux, J. Etchevers, and E. Cerri, 49-64. New York, NY: Food Products Press.

Lal, R., R.F. Follett, and J.M. Kimble. 2003. Achieving soil carbon sequestration in the US: A challenge to the policy makers. Soil Science 168:827-845.

Lokupitiya, E., and K. Paustian. 2006. Agricultural soil greenhouse gas emissions: A review of national inventory method. Journal of Environmental Quality 35:1413-1427.

Luo, Y. 2007. Terrestrial carbon-cycle feedback to climate warming. Annual Review of Ecology, Evolution And Systematics 38:683-712.

Luo, Y., B. Su, W.S. Currie, J.S. Dukes, A. Finzi, U. Hartwig, B. Hungate, R.E. McMurtrie, R. Oren, W.J. Parton, D.E. Pataki, M.R. Shaw, and D.R. Zak. 2004. Progressive nitrogen limitation of ecosystem responses to rising atmospheric carbon dioxide. BioScience 54:731-739.

Montagnini, F., and P.K. Nair. 2004. Carbon sequestration: an underexploited environmental benefit of agroforestry systems. Agroforestry Systems 61:281-295.

Milesi, C., S.W. Running, C.D. Elvidge, J.B. Dietz, B.T. Tuttle, and R.R. Nemani. 2005. Mapping and modeling the biogeochemical cycling of turf grasses in the US. Environmental Management 36(3):426-438.

Mooney, S., J.M. Antle, S.M. Capalbo, and K. Paustian. 2004. Design and costs of a measurement protocol for trades in soil carbon credits. Canadian Journal of Agricultural Economics 52(3):257-287.

Morgan, J.A., D.E. Pataki, C. Korner, H. Clark, S.J. DelGrosso, J.M. Grunzewig, A.K. Knapp, A.R. Mosier, P.C.D. Newton, P.A. Niklaus, J.B. Nippert, R.S. Nowak, W.J. Parton, H.W. Polley and M.R. Shaw. 2004. Water relations in grassland and desert ecosystems to elevated atmospheric $\mathrm{CO}_{2}$. Oecologia 140:11-25.

Nair, P.K.R. and V.D. Nair. 2003. Carbon storage in North US agroforestry systems. The Potential of US Forest Soils to Sequester Carbon and Mitigate the Greenhouse Effect, ed. J. Kimble et al., 333346. Boca Raton, FL: CRC Press.

Parton, W.J., E.A. Holland, S.J. Del Grosso, M.D. Hartman, R.E. Martin, A.R. Mosier, D.S. Ojima, and D.S. Schimel. 2001. Generalized model for $\mathrm{NO}_{\mathrm{x}}$ and $\mathrm{N}_{2} \mathrm{O}$ emissions from soils. Journal of Geophysical Research-Atmospheres 106:17403-17419.

Paustian, K., J. Brenner, M. Easter, K. Killian, S. Ogle, C. Olson, J. Schuler, R. Vining, and S. Williams. 2009. Counting carbon on the farm: Reaping the benefits of carbon offset programs. Journal of Soil and Water Conservation 64:36A-40A.

Pendall, E., J.Y. King, A.R. Mosier, J. Morgan, and D. Milchunas. 2005. Stable isotope constraints on net ecosystem production under elevated $\mathrm{CO}_{2}$. In Stable Isotopes and Biosphere-Atmospheric Interactions: Processes and Biological Controls, ed. L.B. Flanagan, J.R. Ehleringer, and D.E. Pataki, 182-198. San Diego, CA: Elsevier Inc.

Pepper, D.A., S.J. Del Grosso, R.E. McMurtrie, and W.J. Parton. 2005. Simulated carbon sink response of shortgrass steppe, tallgrass prairie and forest 
ecosystems to rising $\left[\mathrm{CO}_{2}\right]$, temperature and nitrogen input. Global Biogeochemical Cycles 19, GB 1004, doi:10.1029/2004GB002226.

Perry, C.H., C.W. Woodhall, G.C. Liknes, and M.M. Schoeneberger. 2009. Filling the gap: Improving the estimates of working tree resources in agricultural lands. Agroforestry Systems 75:91-101.

Qian,Y., and R.F. Follett. 2002. Assessing soil carbon sequestration in turfgrass systems using long-term soil testing data. Agronomy Journal 94:930-935.

Qian, Y, R.F. Follett, and J.M. Kimble. 2010. Soil organic carbon input from urban turfgrasses. Soil Science Society of America Journal. (in press).

Robertson, G.P., V.H. Dale, O.C. Doering, S.P. Hamburg, J.M. Melillo, M.M.Wander,W.J. Parton, R. Pouyat, P.R.Adler, J. Barney, R.M. Cruse, C.S. Duke, P.M. Fearnside, R.F. Follett, H.K. Gibbs, J. Goldemberg, D. Mladenoff, D. Ojima, M.W. Palmer, A. Sharpley, L. Wallace, K.C. Weathers, J.A. Wiens, and W.W. Wilhelm. 2008. Sustainable Biofuels Redux. Science 322:49-50.

Rojstaczer, S., and S.J. Deverel. 1993. Time dependence in atmospheric carbon inputs from drainage of organic soils. Geophysical Research Letters 20:1383-1386.

Ruark, G., M. Schoeneberger, and P.K. Nair. 2003. Agroforestry - helping to achieve sustainable forest management. In The Role of Planted Forests in Sustainable Forest Management: Reports and Papers of the UNFF Intersessional Experts Meeting, 25-27, Wellington, NZ (ISBN-0478-07758-0). http://www.maf.govt. nz/mafnet/unff-planted-forestry-meeting/conference-papers/roles-for-agroforestry.htm.

Runion, G.B., H.A. Torbert, S.A. Prior, and H.H. Rogers. 2009. Effects of elevated atmospheric carbon dioxide on soil carbon in terrestrial ecosystems of the southeastern US. In Soil Carbon Sequestration and the Greenhouse Effect, SSSA Special Publication 57, 2nd ed., ed. R. Lal and R.F. Follett, 233-262, Madison, WI: Soil Science Society of America.

Schnabel, R.R., A.J. Franzluebbers, W.L. Stout, M.A. Sanderson, and J.A. Stuedemann. 2001. The effects of pasture management practices. In The Potential of US Grazing Lands to Sequester Carbon and Mitigate the Greenhouse Effect, ed. R.F. Follett, J.M. Kimble, and R. Lal, 291-322. Boca Raton, FL: CRC Press.

Schoeneberger, M.M. 2009. Agroforestry: working trees for sequestering carbon on agricultural lands. Agroforestry Systems 75:27-37.

Schuman, G.E., J.D. Reeder, J.T. Manley, R.H. Hart, and W.A. Manley. 1999. Impact of grazing management on the carbon and nitrogen balance of a mixed-grass rangeland. Ecological Applications 9:65-71.
Skinner, H. 2007. Winter carbon dioxide fluxes in humid-temperate pastures. Agricultural and Forest Meteorology 144:32-43.

Smith, P. 2004. How long before a change in soil organic carbon can be detected? Global Change Biology 10:1878-1883.

Snyder, G.H. 2005. Everglades Agricultural Area soil subsidence and land use projections. In Proceedings of Soil and Crop Science Society of Florida 64:44-51.

Steenwerth, K., and K.M. Belina. 2008. Cover crops enhance soil organic matter, carbon dynamics and microbiological function in a vineyard agroecosystem. Applied Soil Ecology 40:359-369.

Svejcar, A.J., R.F. Angell, J. Bradford, W. Dugas, W.E. Emmerich, A.B. Frank, T. Gilmanov, M.R. Haferkamp, D.A. Johnson, H.S. Mayeux Jr, P. Mielnick, J.A. Morgan, N. Saliendra, G.E. Schuman, P.L. Sims, and K.A. Snyder. 2008 Carbon fluxes on North American rangelands. Rangeland Ecology and Management 61:465-474.

Swift, R.S. 2001. Sequestration of carbon by soil. Soil Science 166:858-871.

USDA. 2008. US Agriculture and Forestry Greenhouse Gas Inventory: 1990-2005. Global Change Program Office, Office of the Chief Economist, US Department of Agriculture. Tech. Bulletin No. 1921. Washington, DC: USDA. http://www.usda.gov/oce/global_change/ AFGGInventory1990_2005.htm.

USDA ERS (USDA Economic Research Service). 2007. Conservation Policy: Farmland and Grazing Land Protection Programs. Washington, DC: USDA ERS. http://www.ers.usda.gov/Briefing/ ConservationPolicy/farmland.htm.

USDA ERS. 2008. USDA Agricultural Projections to 2017. Interagency Agricultural Projections Committee Long-term Projections Report OCE-2008-1. Washington, DC: USDA ERS. http://www.ers.usda. gov/Publications/OCE081/

USDA NASS (USDA National Agricultural Statistics Service). 2008a. Agricultural Statistics 2008. Washington, DC: US Government Printing Office. http://www.nass.usda.gov/Publications/ Ag_Statistics/2008/TOC2008.pdf

USDA NASS. 2008b. Crop Production Historical Track Records, April 2008. Washington, DC: USDA NASS.

USDA NRCS (USDA Natural Resource Conservation Service). 2003. Annual NRI - Land Use. http://www.nrcs.usda.gov/technical/NRI.

USEPA (United States Environmental Protection Agency). 2008. Inventory of US Greenhouse Gas Emissions and Sinks: 1990-2006. Washington, DC: USEPA, Office of Atmospheric Programs. http://www.epa.gov/climatechange/emissions/ downloads/08_CR.pdf. 